\title{
ISOLATION OF WHITE SPOT SYNDROME VIRUS (WSSV) IN EGYPTIAN SHRIMP USING CONVENTIONAL PCR AND REAL TIME PCR (QPCR) TECHNIQUES
}

\author{
Yaser M. Hafez¹, Nader Y. Moustafa², Asmaa F. Magouz², Naglaa F. Al-Maria1,3*
}

${ }^{1}$ EPCRS Excellence Center \&Plant Pathology and Biotechnology Lab., Faculty of Agriculture, Kafrelsheikh University, Egypt, ${ }^{2}$ Food Control Department, Faculty of Veterinary Medicine, Kafrelsheikh University, 33516, Egypt, ${ }^{3}$ Virology Department, Faculty of Veterinary Medicine, Kafrelsheikh University

*Corresponding author, E-mail: naglaafikry5@yahoo.com

\begin{abstract}
Shrimp aquaculture industry threated by high mortality rates and severe economic losses as a result of white spot syndrome virus (WSSV) infection. Earlyscreening and diagnosis of WSSV are great strategies to decrease the economic losses of the disease on shrimp aquaculture. Therefore, this study was carried out to detect of white WSSV infected shrimp under using two molecular based methods, conventional PCR and qPCR. A total number of 90 samples of red (Aristeus antennatus) and gray (Penaeus latisclcatus) shrimp were collected from Kafr El-Sheikh and Alexandria governorates. External examination of shrimps collected from Kafr El-Sheikh Governorate revealed typical WSSV clinical signs (including loose and easily detached cuticle with appearance of small white spots (3 $\mathrm{mm}$ in diameter) and /or larger patches in the external surface of carapace and cephalothorax. The internal examination showed yellowish white, fragile and swollen hepatopancreas and swollen or shrunken lymphoid tissue. Red shrimp showed slightly obvious white spots without any internal lesions. PCR results confirmed the clinical investigation and postmortem (PM) examination and revealed presence of WSSV partial sequences with a size of $190 \mathrm{bp}$ in shrimp samples from Kafr El-Sheikh Governorate. In contrast, samples collected from Alexandria (Borg El-Arab) gave negative results. The result of qPCR confirmed that obtained by conventional PCR and showed that all positive results of WSSV by conventional PCR gave cycle threshold (Ct) values ranged from 34.81 to 40.06. Our results concluded that, WSSV Diseases of shrimp attack shrimp markets of Kafr El-Sheikh Governorate. The conventional PCR and qPCR based methods for isolation and identification of shrimp WSSV, provided accurate results.
\end{abstract}

Key words: WSSV; PCR; qPCR; shrimp

\section{Introduction}

Shrimp are one of the greatest important food sources for human consumption because shrimp have high levels of omega-3 fatty acids (1). The industry income related to shrimp species is about 50 billion dollars annually (2). Production declining of shrimp was observed 
from 1994 to 1997 in India and from 1997 to 1998 in Asia (3-5). In Egypt, the white spot syndrome virus (WSSV) caused high losses in shrimp fields since 2009 (6). WSSV infects shrimp, lobsters, crayfish and crabs belonging to freshwater and marine crustaceans $(2,7)$.

WSSV is the only member of Whispovirus genus (belong to Nimaviridae family) (8). It is enveloped double stranded circular DNA virus with ovoid to bacilliform shape and a tail like end $(9,10)$. Shrimp aquaculture industry threated by high mortality rates and severe economic losses as a result of WSSV infection. Early-screening and diagnosis of WSSV are great strategies to decrease the economic losses of the disease on shrimp aquaculture. Conventional polymerase chain reaction (PCR), in situ PCR, quantitative PCR, nested PCR as well as loop-mediated isothermal amplification (LAMP) (11-16) has been established for detection of WSSV. The WSSV causes serious economic losses because of high percent of mortality which leads to total crop losses through ten days or less under certain farming conditions (17). The host range of WSSV is at least 78 species, mostly to decapod crustaceans particularly shrimp (18). In coastal area of Egypt, industry depends on shrimp are gradually proceeded to cover the market needs, nevertheless the high risk shrimp farms infected with virus could be disturb the production (19).

To the best of our knowledge, only few researches conducted about WSSV in Egyptian shrimp. Consequently, the goal of this research article was early identification of WSSV in shrimp under Egyptian conditions using of molecular based methods (PCR and qPCR).

\section{Materials and methods}

\section{Shrimp samples}

A total of 90 shrimp samples were collected from two Egyptian Governorates located on Mediterranean Sea; Kafr El-Sheikh and Alexandria. The red shrimp (Aristeus antennatus) and gray shrimp (Penaeus latisclcatus) obtained from Kafr El-sheikh Governorate as well as gray shrimp (Penaeus latisclcatus) obtained from Borg El-Arab farm (Alexandria Governorate).

\section{Conventional PCR assay}

Shrimp samples were prepared for DNA extraction. Carapace and abdominal segments of declining shrimp as well as the control shrimp were split using a scalpel. A part of gills, internal organs, muscle and cuticle are preserved in $-20^{\circ} \mathrm{C}$ for extraction of DNA. Total DNA was extracted according to the instructions of Gene-spin TM Viral Extraction Kit (Intron, South Korea, Cat. No. 1715) and as previously described (20). The PCR reaction mixture was $25 \mu 1$ which consisted of $12.5 \mu 1$ of 2X master mix $(0.1 \mathrm{U} / \mu \mathrm{l}$ Taq polymerase, 500 $\mu \mathrm{M}$ dNTP, 20mM Tris-HCl (pH8.3), 100mM $\mathrm{KCl}, 3 \mathrm{mM} \mathrm{MgCl} 2$ and Stabilizer and enhancer), $1 \mu 1$ of 10 pmol of each primer, and $2 \mu \mathrm{L}$ of template DNA $(50 \mu \mathrm{g} / \mathrm{ml})$. The primers were designed as previously described (19). Amplification was performed in a thermocycler (Bio-Rad, C - 1000). The amplified products were examined on $1.5 \%$ agarose gel. Ten $\mu \mathrm{L}$ of amplified product, negative control were injected into the well then run with $50 \mathrm{bp}$ DNA ladder in $1 \mathrm{X}$ TAE electrophoresis buffer (5 volts $/ \mathrm{cm} 2$ for $45 \mathrm{~min}$.). At the end of the run of electrophoresis, the gel was captured by a gel documentation system. The expected DNA fragments were 190 base pairs (bp) in length.

\section{Real time PCR assay}

A single tube qPCR reaction was adjusted according to the kit manual instruction. In brief, the reaction mixture was $25 \mu 1$ which consisted of $12.5 \mu 1$ of $2 X$ SYBR Green qPCR Master Mix, $1 \mu 1$ of 10 pmol of each primer (5AATGGTCCCGTCCTCATCTCA-3) as well as (5-GCTGCCTTGCCGGAAATT-3) specific for WSSV (15), and $2 \mu \mathrm{L}$ of template DNA (50 $\mu \mathrm{g} / \mathrm{ml})$. PCR was conducted in an eppendorf thermal cycler amplification was performed in a thermocycler (Real time PCR-Agilent Technologies - Stratagene MX300P). Early denaturation at $94{ }^{0} \mathrm{C}$ for $5 \mathrm{~min}$, then cyclic condition was 35 cycles at $94{ }^{0} \mathrm{C}$ for $30 \mathrm{sec}$, annealing at $54{ }^{\circ} \mathrm{C}$ for $1 \mathrm{~min}$ as well as extension at $72{ }^{\circ} \mathrm{C}$ for $1 \mathrm{~min}$. The final extension at $72{ }^{\circ} \mathrm{C}$ for $10 \mathrm{~min}(15,20)$. The melting temperature for all obtained products was $80^{\circ} \mathrm{C}$ indicating 
the specificity of primers annealing to the template.

\section{Results}

\section{Results of gross pathology}

The collected shrimps collected from Kafr El-Sheikh Governorate were suspected to be infected with White Spot Syndrome virus (WSSV) based on the following main symptoms: loose and easily detached cuticle with appearance of white spots $(3 \mathrm{~mm}$ in diameter) in external surface carapace and cephalothorax (Fig.1). These spots were not easy to be removed and in some region, they collected forming large patches of different sizes with whitish circular spots. The internal examination of these shrimps revealed yellowish white, fragile and swollen hepatopancreas and swollen and shrunken lymphoid tissue (Fig.1). In addition to accumulation of the fluids that caused swelling of bronchiostegites. On the other hand, red shrimp showed slightly obvious white spots without any internal lesions (Fig.1).

\section{Results of conventional PCR}

PCR results confirmed the clinical investigation and postmortem (PM) examination and revealed presence of WSSV partial sequences with a size of $190 \mathrm{bp}$ in shrimp samples which had WSSV gross lesions obtained from Kafr El-Sheikh Governorate (Fig. 2). In contrast, samples collected from Alexandria (Borg El-Arab) gave negative results. PCR products of infected shrimp samples of different species revealed that 54 out of 60 shrimp samples from Kafr El-sheikh Governorate were PCR positive. Meanwhile, 30 samples collected from Borg El-Arab Alexandria Governorate gave negative (-ve) results (Fig. 2).

Our results cleared that, there was a significant differences of the incidences of WSSV $(\mathrm{P}<0.01)$ among the type of shrimp and among different regions. The results cleared that, the degree of WSSV infected shrimp from Kafr El-sheikh markets showed high incidences to WSSV infection however, no disease incidence were recorded in Alexandria gray shrimp (Table 1).

\section{qPCR results of WSSV in shrimp samples}

The 90 samples were examined with real time PCR using specific primers for WSSV. The result showed that all positive results of WSSV by conventional PCR gave cycle threshold $(\mathrm{Ct})$ values ranged from 34.81 to 40.06 (Table 2, Fig. 3).

Table 1: Incidences of isolated WSSV among examined shrimp after conventional PCR

\begin{tabular}{|c|c|c|c|c|c|c|}
\hline $\begin{array}{l}\text { Number of } \\
\text { sample }\end{array}$ & $\begin{array}{l}\text { Number of } \\
\text { positive } \\
\text { sample }\end{array}$ & Locality & $\begin{array}{l}\text { Site of } \\
\text { DNA } \\
\text { extraction }\end{array}$ & $\begin{array}{l}\text { Appearance } \\
\text { of symptoms }\end{array}$ & Results & $\%$ of infection \\
\hline 15 & 14 & $\begin{array}{l}\text { Kafr-Elsheikh } \\
\text { Kafr-Elsheikh }\end{array}$ & $\begin{array}{l}\text { Cuticle of } \\
\text { red shrimp }\end{array}$ & $\begin{array}{l}\text { Have } \\
\text { symptoms }\end{array}$ & $\begin{array}{l}\text { +ve } \\
\text { (WSSV) }\end{array}$ & $93.3 \%$ \\
\hline 15 & 13 & Kafr-Elsheikh & $\begin{array}{l}\text { Cuticle of } \\
\text { gray shrimp }\end{array}$ & $\begin{array}{l}\text { Have } \\
\text { symptoms }\end{array}$ & $\begin{array}{l}\text { +ve } \\
\text { (WSSV) }\end{array}$ & $92.9 \%$ \\
\hline 15 & 13 & Kafr-Elsheikh & $\begin{array}{l}\text { Internal } \\
\text { organs of } \\
\text { gray shrimp }\end{array}$ & $\begin{array}{l}\text { Have } \\
\text { symptoms }\end{array}$ & $\begin{array}{l}\text { +ve } \\
\text { (WSSV) }\end{array}$ & $92.9 \%$ \\
\hline 15 & 14 & & $\begin{array}{l}\text { Internal } \\
\text { organs of } \\
\text { red shrimp }\end{array}$ & $\begin{array}{l}\text { Have } \\
\text { symptoms }\end{array}$ & $\begin{array}{l}\text { +ve } \\
\text { (WSSV) }\end{array}$ & $93.3 \%$ \\
\hline 15 & 0 & Alexandria & $\begin{array}{l}\text { Cuticle of } \\
\text { gray shrimp }\end{array}$ & $\begin{array}{l}\text { No } \\
\text { symptoms }\end{array}$ & -ve (WSSV) & 0 \\
\hline 15 & 0 & Alexandria & $\begin{array}{l}\text { Internal } \\
\text { organs of } \\
\text { gray shrimp }\end{array}$ & $\begin{array}{l}\text { No } \\
\text { symptoms }\end{array}$ & -ve (WSSV) & 0 \\
\hline
\end{tabular}


Table 2: Mean of Cycle Threshold of samples examined for WSSV using qPCR

\begin{tabular}{llll}
\hline Samples NO. & Site of DNA extraction & $\begin{array}{l}\text { Mean of } \\
\text { Threshold }\end{array}$ & Cycle \\
\hline 1 & Cuticle of red shrimp from Kafr-Elsheikh & 40.06 & \\
2 & Cuticle of gray shrimp from Kafr-Elsheikh & 36.01 & \\
3 & Internal organs of gray shrimp from Kafr-Elsheikh & 34.81 & \\
4 & Internal organs of red shrimp from Kafr-Elsheikh & 37.60 & \\
5 & Cuticle of gray shrimp from Alexandria & 0.0 & \\
6 & Internal organs of gray shrimp from Alexandria & 0.0 & \\
\hline
\end{tabular}

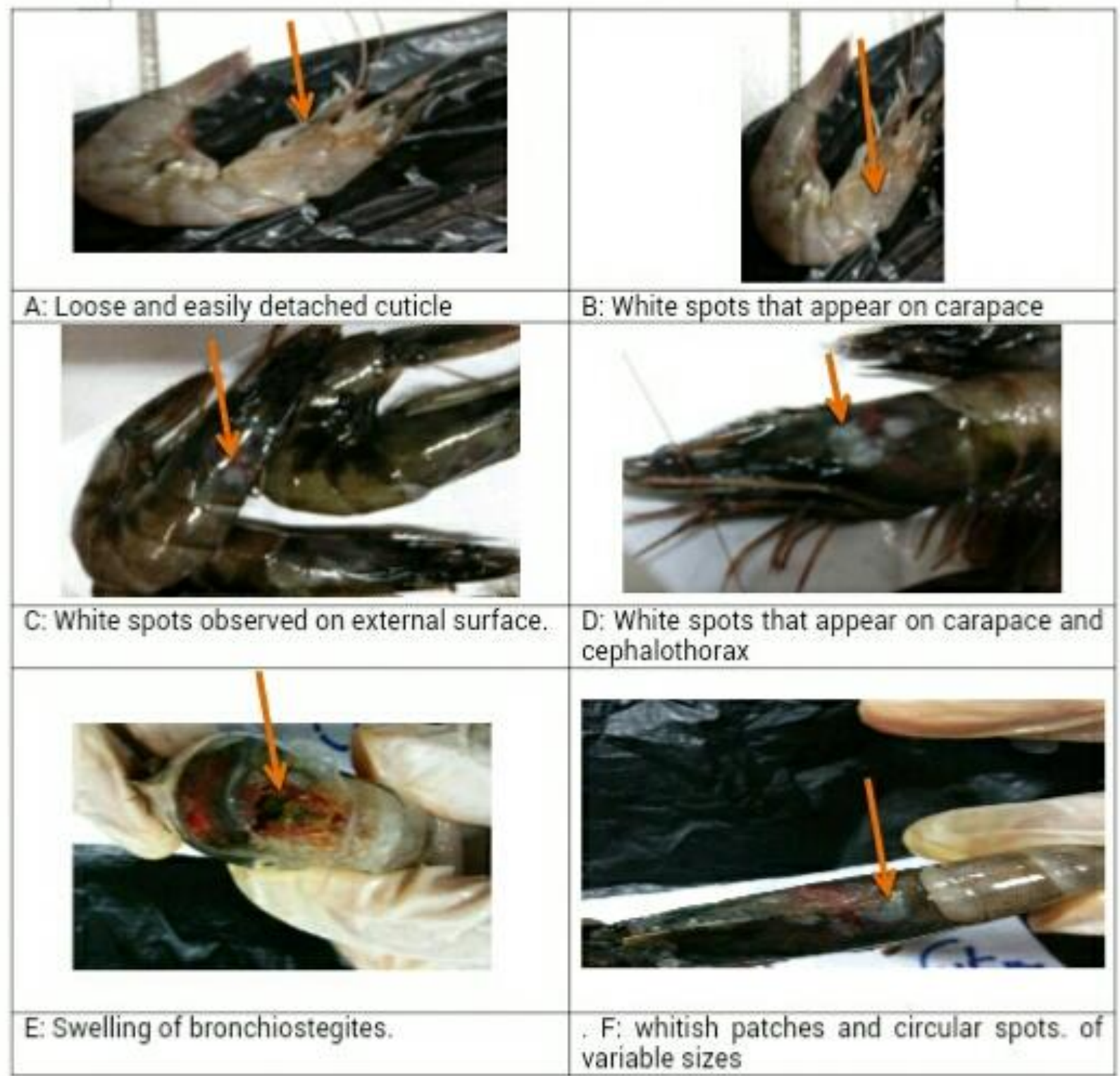

Figure 1: White spot syndrome virus (WSSV) infection gross lesion on shrimp. A, B: from red shrimp. C- F: from gray shrimp 


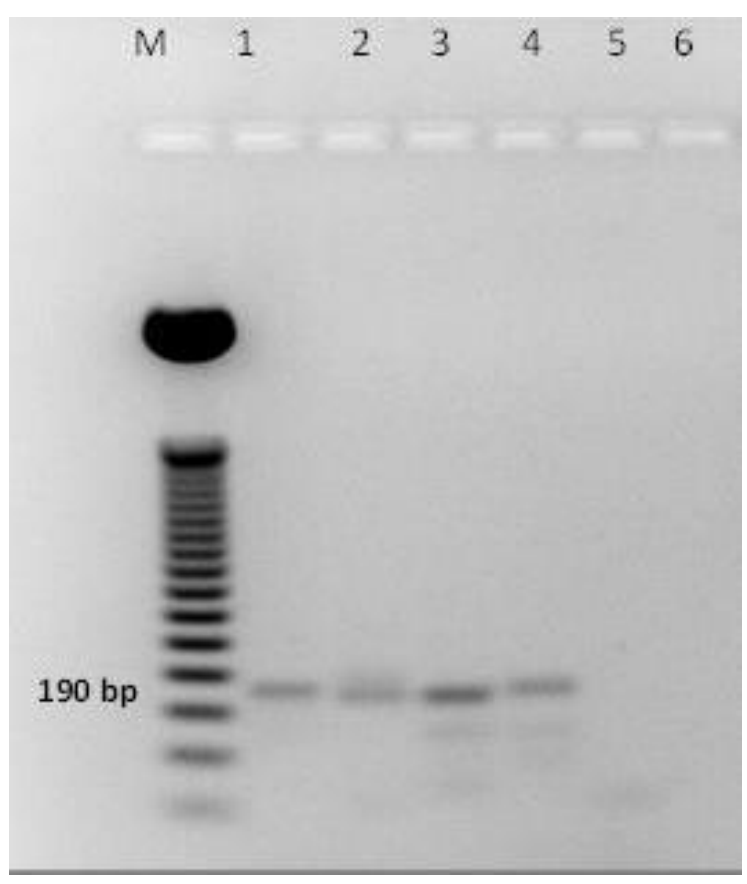

Figure 2: PCR results of WSSV on agarose gel. $M=50$ bp ladder, $1=$ (sample from cuticle of red shrimp), $2=($ sample from cuticle of gray shrimp), $3=$ (sample from internal organs of gray shrimp), $4=$ (sample from internal organs of red shrimp), $5=$ (sample from cuticle of gray shrimp), $6=$ (sample from internal organs of gray shrimp). 1-4 samples collected from Kafr EL-sheikh, 5-6 samples collected from Alexandria

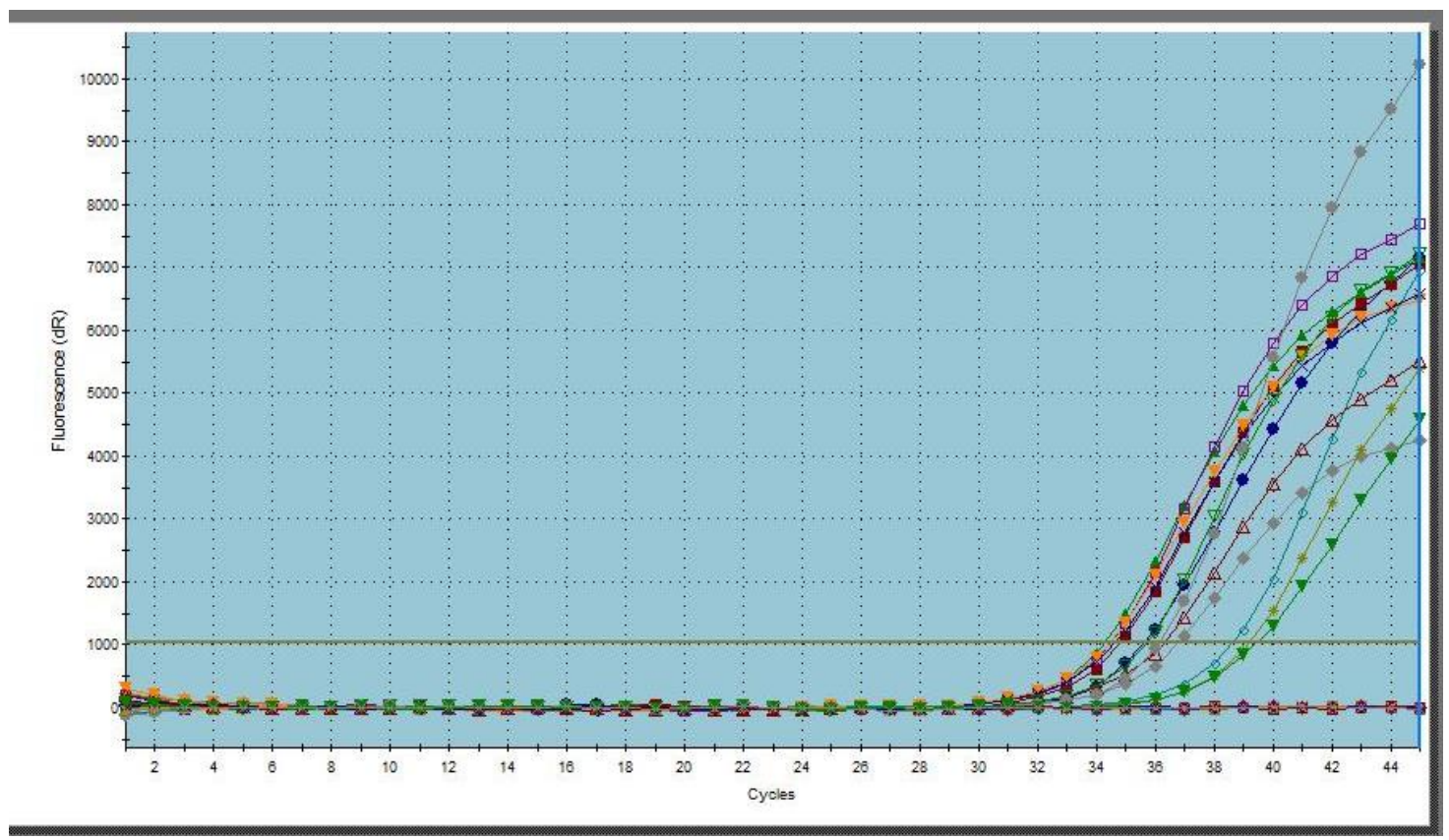

Figure 3: Amplification curves of real time PCR results of WSSV

\section{Discussion}

WSSV is one of the most serious shrimp disease which does not only attack shrimp farms in Egypt and causes economic losses but also infects other freshwater and marine crustaceans, mostly crayfish and crabs $(1,9)$.
The virus is so dangerous so that can lead to $100 \%$ mortalities during only 2-10 days from appearance of symptoms $(2,21)$. Little information and knowledges about the incidences and prevalence of this virus in shrimp aquaculture have been reported in Egypt. Although the shrimp aquaculture 
became more advanced in Egypt, the infected shrimp threaten shrimp farming. Thus, control WSSV is required to avoid shrimp losses. The aim of this study was to throw the light on the occurrence and incidences of WSSV in some two species of the shrimp present in Egypt.

Our results revealed that 54 out of 60 shrimp samples collected from Kafr El-sheikh Governorate showed positive results for WSSV however, no positive results were obtained from the 30 total shrimp samples collected from Alexandria Governorate. These results supported by the results obtained by Megahed et al 2019, Eissa et al 2009 and Salama et al $2008(6,19,22)$ and confirming WSSV identification among Egyptian shrimps.

Herein, gross pathological examination revealed presence of white spots on the shrimp body after removal of cephalothorax cuticle. Our results agreed with those obtained by $(2$, 23-26) who also found cuticle chromophores and calcium deposition. Although we did not find softening of exoskeleton, in many epizootics of this disease, this softening could be observed. Changes in the structural integrity of the exo and pro cuticle could be the most vital reason for WSSV syndrome (28-30). The obtained internal examination results agreed with $(2,27,31)$ and proved that white spot virus infected hepatopancreatic sheath.

PCR (both conventional and real time) confirmed presence of WSSV in shrimps collected from Kafr El-sheikh Governorate. In the present study, 90 shrimp samples were examined with conventional PCR using specific primers of WSSV. The result showed that 54 out of 60 gray and red shrimp samples of Kafr El-sheikh Governorate were PCR positive. Meanwhile 30 gray shrimp samples collected from Borg El-Arab, Alexandria Governorate gave negative (-ve) results. Results from conventional PCR were further confirmed by qPCR which showed amplification curves with $\mathrm{Ct}$ values ranged from 34.81 to 40.06 in all conventional PCR positive samples. PCR has been applied for the diagnosis of WSSV infections in clinical samples and shown to be rapid, sensitive and specific diagnostic method (32-35).

\section{Conclusion}

To the best of our knowledge, this may be the first study to detect shrimp WSSV in Egypt using qPCR. The conventional PCR and qPCR based methods are successful methods for early identification of WSSV in clinical samples of infected shrimp that delivers accurate tool for identification of this virus.

\section{Acknowledgment}

This research article was conducted in accredited Plant Pathology and Biotechnology Lab. (PPBL) and certified EPCRS Excellence Centre, Faculty of Agriculture, Kafrelsheikh University. We thank staff members at PPBL, EPCRS and Department of Fish Diseases and Management, Faculty of Veterinary Medicine, Kafrelsheikh University.

\section{References}

1. Shahidy MS, El-Gamal RM, Dessouki A. et al. Detection of white spot syndrome in cultured penaeid shrimp in Egypt: histopathological observation and polymerase chain reaction. MENA Science Journal 2015; 1(1): 5-14.

2. Tao M, Zhou H, Luo K, Lu J, Zhang Y, Wang F. Quantitative serum proteomics analyses reveal shrimp responses against WSSV infection. Dev Comp Immunol. 2019; 93:89-92.

3. Sharawy ZZ, Thiele R, Abbas EM, El-Magd MA, Hassaan MS, Peter C, Schmidt J, Saborowski R, Goda AMA-S, Slater MJ. Antioxidant response, body composition of whiteleg shrimp Litopenaeus vannamei co-cultured with Nile tilapia Oreochromis niloticus in recirculating aquaculture. Aquaculture Environment Interactions 2017; 9:257-68.

4. Pillai, N.G.K.; Katiha, P.K. Evolution of fisheries and aquaculture in India. Central Marine Research Institute, Kochi, India 2004; p240.

5. FAO. Fishery and Aquaculture Statistics. FAO Year Book 2006. Food and Agriculture Organization of the United Nations, Rome 2008; p57.

6. Megahed ME, Kanrar S, Dhar AK. Complete Genome Sequence of White Spot Syndrome Virus Isolated from Indian White Prawn (Fenneropenaeus indicus) in Egypt. Microbiol Resour Announc 2019; 3(1): 8-14.

7. Tsai Y, Lina Y, Choua P, et al. Detection of white spot syndrome virus by polymerase chain reaction performed under insulated isothermal 
conditions. Journal of Virological Methods 2012; 181(1):134-7.

8. Mayo, M. A. A summary of taxonomic changes recently approved by ICTV. Archives of Virology2002; 147, 1655-63.

9. Van Hulten M, Witteveldt J, Peters S. et al. The white spot syndrome virus DNA genomic sequence. Virology 2001; 286: 7-22.

10. Yang F, He J, Lin X, et al. Complete genome sequence of the shrimp white spot bacilliform virus. Journal of Virology 2001; 75: 11811-20.

11. Vaseeharan B, Jayakumar R, and Ramasamy, A. PPCR-based detection of white spot syndrome virus in cultured and captured crustaceans in India. Lett. Appl. Microbiol 2003; 37: 443-7.

12. Jian X, Lu L, Chen Y, et al. Comparison of a novel in situ polymerase chain reaction (ISPCR) method to other methods for white spot syndrome virus (WSSV) detection in Penaeus vannamei. Dis. Aquat. Organ 2005; 67: 171-6.

13. Durand S, and Lightner D. Quantitative realtime PCR for the measurement of white spot syndrome virus in shrimp. J. Fish Dis.2002; 25: 381-9.

14. Nunan, L, and Lightner D. Optimized PCR assay for detection of white spot syndrome virus (WSSV). J. Virol. Methods 2011; 171: 318-21.

15. Chou P, Lin Y, Teng P, et al. Real-time target-specific detection of loop-mediated isothermal amplification for white spot syndrome virus using fluorescence energy transfer-based probes. J. Virol. Methods 2011; 173: 67-74.

16. Kono T, Savan R, Sakai M, Itami T. Detection of white spot syndrome virus in shrimp by loop-mediated isothermal amplification. J. Virol. Methods 2004; 115: 59-65.

17. Pradeep B, Karunasagar I and Karunasagar I. Fitness and virulence of different strains of white spot syndrome virus. Journal of Fish Diseases 2009; 32: 801-5.

18. Flegel TW. Detection of major penaeid shrimp viruses in Asia, a historical perspective with emphasis on Thailand. Aquaculture 2006; 258: 133.

19. Eissa I, Badran A, Diab A, et al. Diagnosis of white spot syndrome virus (WSSV) among shrimp for the first time in Egypt. SCVMJ, VIX 2009; (1).

20. Orabi A, Hussein A, Saleh A A, El-Magd M A, Munir M. Evolutionary insights into the fusion protein of Newcastle disease virus isolated from vaccinated chickens in 2016 in Egypt, Archives of Virology 2017; 162(10): 3069-79.
21. Lightner DV. A handbook of pathology and diagnostic procedures for diseases of penaeid shrimp. Baton Rouge, Louisiana, USA: World Aquaculture Society 1996.

22. Salama A, Diab A, Abd El-Samie, A, and Abdel-Wahab A. Isolation and Identification of White Spot Syndrome Virus. Zag. Vet. J. 2008; (ISSN. 1110-1458) Vol.36, No. 4 pp.105-13.

23. Wang Y, Lee K, Najiah M. et al. A new bacterial white spot syndrome (BWSS): in cultured tiger shrimp Penaeus monodon and its comparison with white spot syndrome (WSS): caused by virus. Dis. Aquat. Org.2002; 41 (1): 9-18.

24. Lotz J, and Soto M A. Model of white spot syndrome virus (WSSV) epidemics in Litopenaeus vannamei. Diseases of Aquatic Organisms 2002; 50: 199-209.

25. Wu W, Wang $\mathrm{L}$ and Zhang X. Identification of white spot syndrome virus (WSSV) envelope proteins involved in shrimp infection. Virology 2005; 332: 578-83.

26. Chen L, Leu J, Huang C. et al. Identification of a nucleocapsid protein (VP35) gene of shrimp white spot syndrome virus and characterization of the motif important for targeting VP35 to the nuclei of transfected insect cells. Virology 2002; 293: 4453.

27. Wang Q, White B, Redman R and Lightner D. Per os challenge of Litopenaeus vannamei postlarvae and Farfantepenaeus duorarum juveniles with six geographic isolates of white spot syndrome virus. Aquaculture 1999; 170: 179-194.

28. Kasornchandra J, Boonyaratpalin S, and Itami T. Detection of white spot syndrome in cultured penaeid shrimp in Asia: microscopic observation and polymerase chain reaction. Aquaculture 1998; 164: 243-51.

29. Peng S, Lo C, Ho C et al. Detection of white spot baculovirus (WSBV) in giant fresh water prawn; Macrobrachium rosenbergii using polymerase chain reaction. Aquaculture 1998; 164: 253-62.

30. Karunasagar I, Otta S and Karunasagar I. Histopathological and bacteriological study of white spot syndrome of Penaeus monodon along the west coast of India. Aquaculture 1997; 153: 913.

31. Chang $\mathrm{P}$, Lo $\mathrm{C}$, Wang $\mathrm{Y}$, and Kou G. Identification of white spot syndrome virus associated baculovirus (WSBV) target organs in the shrimp Penaeus monodon by in situ hybridization. Diseases of Aquatic Organisms 1996; 27: 131-9.

32. Lo C, Leu J, Ho C, et al. Detection of baculovirus associated with white spot syndrome 
(WSBV) in penaeid shrimps using polymerase chain reaction. Dis. Aquat. Org.1996; 25: 133-41.

33. Wang $\mathrm{Y}$, Lo $\mathrm{C}$, Chang $\mathrm{P}$ and Kou G. Experimental infection of white spot baculovirus in some cultured and wild decapods in Taiwan. Aquaculture 1998; 164: 221-31.

34. Tang KFJ. Lightner, D.V. Quantification of white spot syndrome virus DNA through a compe- titive polymerase chain reaction. Aquaculture 2000; 189: 11-21.

35. Kathy Tang-Nelson and Donald V. Lightner. Development of real-time PCR assays for detection of white spot syndrome virus, yellow head virus, Taura syndrome virus, and infectious hypodermal and hematopoietic necrosis virus in penaeid shrimp 2001, NA06FD0448. 